\title{
Design and synthesis of novel thiophenecarbohydrazide, thienopyrazole and thienopyrimidine derivatives as antioxidant and antitumor agents
}

\author{
AMEEN ALI ABU-HASHEM ${ }^{1}$ \\ MOHAMED FATHY EL-SHEHRY ${ }^{2 *}$ \\ FARID ABD-ELRAHEEM BADRIA ${ }^{3}$ \\ 1 Photochemistry Department \\ (Heterocyclic Unit), National \\ Research Center, 12622 Dokki \\ Giza, Egypt \\ 2 Green Chemistry Department \\ National Research Center \\ 12622 Dokki, Giza, Egypt \\ ${ }^{3}$ Department of Pharmacognosy \\ Faculty of Pharmacy, Mansoura \\ University, 35516 Mansoura, Egypt
}

2-Amino-5-acetyl-4-methyl-thiophene-3-carboxylic acid ethyl ester (1) and 5-acetyl-2-amino-4-methylthiophene-3-carbohydrazide (2) were synthesized and used as starting materials for the synthesis of new series of 1-(5-amino-4-(3,5-dimethyl-1H-pyrazole-1-carbonyl)-3-methylthiophen-2-yl) ethanone (3a), 1-(5-amino-4-(4-chloro-3,5-dimethyl-1H-pyrazole-1-carbonyl)-3-methylthiophen-2-yl) ethanone (3b), 1-(4-methyl-2-amino-5-acetylthiophene-3-carbonyl)pyrazolidine-3,5-dione (4), (Z)-N'-(4 -methyl-2-amino-5-acetylthiophene-3-carbonyl) formohydrazonic acid (5a), (Z)-ethyl-N'-4-methyl-2-amino-5-acetylthiophene-3-carbonylformo hydrazonate (5b), 6-acetyl-3-amino-2,5-dimethylthieno[2,3- $d$ ]pyrimidin-4(3H)-one (8), 5-methyl-3-amino-2-mercapto-6-acetylthieno [2,3-d]pyrimidin-4(3H)-one (10) and 5-methyl-6-acetyl-2-thioxo-2,3-dihydrothieno[2,3-d]pyrimidin-4(1H)-one (12) as potential antioxidant and antitumor agents. Pharmacological tests showed that compounds $6 \mathbf{a}, 6 \mathbf{b}, 8,10$ and 12 exhibited significant antitumor and antioxidant activity.

Keywords: thienopyrazole, thieno[2,3-d]pyrimidines, thiophenecarbohydrazide, antioxidant activity, bleomycin-dependent DNA damage, antitumor activity

The ultimate position of substituted 2-aminothiophenes in the field of drug design and synthesis of pharmaceuticals comes from their advantageous properties. The thiophene ring is bioisosteric replacement for the phenyl group broadly present in active drugs; the thiophene core exists in many natural and synthetic pharmaceuticals $(1,2)$. In the present work, ethyl-2-aminothiophene-3-carboxylic was expressed as a synthone for many new condensed heterocyclic systems viz. thieno[2,3- $d]$ pyrimidine, thienylthiourea, thienylacetamide, thienylcarbohydrazide. Fused and polyfunctional substituted thiophene play an important role, especially when linked to a pyrimidine ring; thienopyri-

*Correspondence; e-mail: moh_elshehry2000@yahoo.com 
A. A. Abu-Hashem et al.: Design and synthesis of novel thiophenecarbohydrazide, thienopyrazole and thienopyrimidine derivatives as antioxidant and antitumor agents, Acta Pharm. 60 (2010) 311-323.

midine derivatives possess pharmacological properties as $\mathrm{A}_{1}$ adenosine receptor agonists $(3,4)$, phosphodiesterase inhibitors and many receptor antagonists $(5,6)$. Various thieno $[2,3-d]$ pyrimidine derivatives show pronounced antitumor (7) and radioprotective activities (8), acts as immunomodulators (9) and were used for prophylaxis and therapy of cerebral ischemia (10), malaria (11), tuberculosis (12), Alzheimer's disease (13), Parkinson's disease $(14)$, and other diseases $(15,16)$. Design and synthesis of the novel thiophenecarbohydrazide, thienopyrazole and thienopyrimidine derivatives as antioxidant and antitumor agents were explored.

\section{EXPERIMENTAL}

All melting points were taken on an Electrothermal IA 9100 series digital melting point apparatus (Shimadzu, Japan). Elemental analyses were performed at Vario EL (Elementar, Germany). Microanalytical data were processed in the microanalytical center, Faculty of Science, Cairo University. The IR spectra (KBr disk) were recorded using a Perkin-Elmer 1650 spectrometer (USA). ${ }^{1} \mathrm{H}$ NMR spectra were determined using Jeol 270 $\mathrm{MHz}$ and Jeol JMS-AX $500 \mathrm{MHz}$ (Jeol, Japan) with internal standard $\mathrm{MeSi}_{4}$. Mass spectra were recorded on an EI Ms-QP 1000 EX (Shimadzu) at $70 \mathrm{eV}$. Pharmacological evaluations were done in pharmacological unit, Department of Pharmacognosy, Faculty of Pharmacy, Mansoura University, Egypt.

DNA (calf thymus type 1), bleomycin sulfate, butylated hydroxyanisole (BHA), thiobarbituric acid (TBA), ethylenediaminetetraacetic acid (EDTA) and ascorbic acid were obtained from Sigma (USA). 2,2'-Azo-bis-(2-amidinopropane) dihydrochloride (AAPH), 2,2'-azino-bis-3-ethylbenzthiazoline-6-sulfonic acid (ABTS) were purchased from Wako Co. (USA).

\section{Syntheses}

Ethyl-4-methyl-2-amino-5-acetylthiophene-3-carboxylate (1). - A mixture of acetylacetone $(0.01 \mathrm{~mol})$, ethyl cyanoacetate $(0.01 \mathrm{~mol})$, sulfur $(0.01 \mathrm{~mol})$ and diethylamine $(0.01 \mathrm{~mol})$ was heated at $70{ }^{\circ} \mathrm{C}$ under stirring in absolute ethanol $(20 \mathrm{~mL})$ for $4 \mathrm{~h}$, then the mixture was left for $24 \mathrm{~h}$ at $0{ }^{\circ} \mathrm{C}$. The solid formed was collected by filtration, washed with ethanol $(20 \mathrm{~mL})$, dried and crystallized from absolute ethanol.

5-Acetyl-2-amino-4-methylthiophene-3-carbohydrazide (2). - A suspension of dry compound $1(0.01 \mathrm{~mol})$ and hydrazine hydrate $(5 \mathrm{~mL})$ and $(30 \mathrm{~mL})$ absolute ethanol was stirred under gentle reflux. The solid dissolved within 10 min with copious evolution of hydrogen sulfide to form a clear solution. After $30 \mathrm{~min}$, the solid product started separating out; heating was continued for $8 \mathrm{~h}$. The reaction mixture was then allowed to cool to room temperature. The solid was filtered off, washed with ethanol, dried and crystallized from dioxane.

1-(5-Amino-4-(3,5-dimethyl-1H-pyrazole-1-carbonyl)-3-methylthiophen-2-yl) ethanone (3a) and 1-(5-amino-4-(4-chloro-3,5-dimethyl-1H-pyrazole-1-carbonyl)-3-methylthiophen-2-yl) ethanone (3b). - A mixture of compound $2(0.01 \mathrm{~mol})$ and 2,4-diketone, namely, pentan-2,4-dione 
A. A. Abu-Hashem et al.: Design and synthesis of novel thiophenecarbohydrazide, thienopyrazole and thienopyrimidine derivatives as antioxidant and antitumor agents, Acta Pharm. 60 (2010) 311-323.

or 3-chloropentan-2,4-dione $(0.01 \mathrm{~mol})$ in absolute ethanol $(30 \mathrm{~mL})$, was stirred under reflux for $12 \mathrm{~h}$. The reaction mixture was allowed to cool to $0{ }^{\circ} \mathrm{C}$ for $24 \mathrm{~h}$, the solid precipitate was filtered off, dried and crystallized from ethanol to produce $\mathbf{3 a}$ or $\mathbf{3 b}$ in high yields.

1-(4-Methyl-2-amino-5-acetylthiophene-3-carbonyl)pyrazolidine-3,5-dione (4). - A solution of compound $2(0.01 \mathrm{~mol})$ and freshly distilled diethylmalonate $(0.01 \mathrm{~mol})$ in sodium ethoxide was heated under reflux with stirring for $5 \mathrm{~h}$. The solvent was evaporated under reduced pressure and the crude product was acidified with $10 \%$ hydrochloric acid. The solid formed was filtered off, washed with cold water, and crystallized from ethanol.

(Z)-N'-(4-methyl-2-amino-5-acetylthiophene-3-carbonyl) formohydrazonic acid (5a). - A mixture of compound $2(0.01 \mathrm{~mol})$ and formic acid $(10 \mathrm{~mL})$ was heated under reflux for $6 \mathrm{~h}$. The reaction mixture was allowed to cool to room temperature and poured onto water $(100 \mathrm{~mL})$. The solid formed was collected by filtration, dried, and crystallized from benzene.

(Z)-ethyl-N'-4-methyl-2-amino-5-acetylthiophene-3-carbonylformo hydrazonate (5b). - A mixture of compound $2(0.01 \mathrm{~mol})$ and triethylorthoformate $(20 \mathrm{~mL})$ was heated under reflux with stirring for $2 \mathrm{~h}$. The reaction mixture was filtered hot and the filtrate was left to cool to room temperature. The solid formed was filtered off, dried and crystallized from ethanol.

Synthesis of 1-(5-amino-3-methyl-4-(1,3,4-oxadiazol-2-yl) thiophen-2-yl) ethanone (6a) and 1-(5-amino-3-methyl-4-(1,3,4-oxathiadiazol-2-yl) thiophen-2-yl) ethanone (6b). - A mixture of compounds $5 \mathbf{a}$ or $5 \mathbf{b}(0.005 \mathrm{~mol})$ and phosphorus pentoxide $(2 \mathrm{~g})$ or phosphorus pentasulfide ( $4 \mathrm{~g})$ in dry xylene $(30 \mathrm{~mL})$ was heated under reflux for 6-12 h. The solid separated upon cooling was filtered off, crystallized from ethanol to produce $6 \mathbf{a}$ and $\mathbf{6 b}$, respectively.

Ethyl-2-acetamido-4-methyl-5-acetylthiophene-3-carboxylate (7). - A mixture of compound $1(0.01 \mathrm{~mol})$ and acetic anhydride $(30 \mathrm{~mL})$ was heated under reflux for $3 \mathrm{~h}$. The reaction mixture was allowed to cool to room temperature and the solid formed was collected by filtration, dried, and crystallized from ethanol.

6-Acetyl-3-amino-2,5-dimethylthieno[2,3-d]pyrimidin-4(3H)-one (8). - A mixture of 7 $(0.01 \mathrm{~mol})$ and hydrazine hydrate $(10 \mathrm{~mL})$ in ethanol $(30 \mathrm{~mL})$ was heated under reflux for $2 \mathrm{~h}$. The reaction mixture was allowed to cool to room temperature and poured into water $(100 \mathrm{~mL})$. The solid formed was collected by filtration, dried and crystallized from ethanol as yellow powder.

Ethyl-4-methyl-5-acetyl-2-(methylthiocarbonothioylamino) thiophene-3-carboxylate (9). To a vigorously stirred solution of $1(0.02 \mathrm{~mol})$ in dimethylsulfoxide DMSO $(10 \mathrm{~mL})$ at room temperature, carbon disulfide $(0.026 \mathrm{~mol})$ and aqueous sodium hydroxide were added simultaneously over $30 \mathrm{~min}$; stirring was continued for further $30 \mathrm{~min}$. Dimethylsulfate $(0.02 \mathrm{~mol})$ was added dropwise to the reaction mixture under stirring at $5-10{ }^{\circ} \mathrm{C}$. It was stirred for another $2 \mathrm{~h}$ and poured into ice-water. The solid obtained was filtered off, dried and recrystallized from ethanol. 
A. A. Abu-Hashem et al.: Design and synthesis of novel thiophenecarbohydrazide, thienopyrazole and thienopyrimidine derivatives as antioxidant and antitumor agents, Acta Pharm. 60 (2010) 311-323.

5-Methyl-3-amino-2-mercapto-6-acetylthieno[2,3-d]pyrimidin-4(3H)-one (10). - Method A: A solution of $9(0.01 \mathrm{~mol})$ in ethanol $(30 \mathrm{~mL})$ and hydrazine hydrate $(0.01 \mathrm{~mol})$ was added and refluxed on a water bath until the methyl mercaptan evolution ceased after $8 \mathrm{~h}$. After cooling, the solid obtained was filtered off, dried and recrystallized from ethanol/ acetone mixture. Method B: A solution of $2(0.01 \mathrm{~mol})$ in ethanol $(30 \mathrm{~mL})$ and aqueous potassium hydroxide $(0.01 \mathrm{~mol})$ was refluxed for $30 \mathrm{~min}$. After cooling to room temperature, carbon disulfide $(1 \mathrm{~mL})$ was added, refluxed for 2-3 hours and poured into ice-water. The solid obtained was filtered off, dried and recrystallized from ethanol.

Ethyl-4-methyl-5-acetyl-2-thioureidothiophene-3-carboxylate (11). - A mixture of 1 (0.01 $\mathrm{mol})$ and $10 \% \mathrm{HCl}(10 \mathrm{~mL})$ was refluxed with potassium thiocyanate $(0.015 \mathrm{~mol})$ for $4 \mathrm{~h}$. The reaction mixture was allowed to cool to room temperature. The solid formed was collected by filtration, washed with water, dried and crystallized from dioxane.

5-Methyl-6-acetyl-2-thioxo-2,3-dihydrothieno[2,3-d]pyrimidin-4(1H)-one (12). - A solution of $11(0.01 \mathrm{~mol})$ in ethanolic sodium ethoxide $(0.23 \mathrm{~g}$ of sodium metal in $30 \mathrm{~mL}$ ethanol) was stirred under reflux for $6 \mathrm{~h}$. After cooling, the reaction mixture was neutralized with cool $10 \% \mathrm{HCl}$ and the solid formed was collected by filtration, washed with water, dried and then crystallized from dimethylformamide.

\section{Pharmacological screening}

Ehrlich cells. - Ehrlich cells (Ehrlich ascites carcinoma, EAC) were derived from ascetic fluid from diseased mice (the cells were purchased from the National Cancer institute, Cairo, Egypt).

Antioxidant activity screening via erythrocyte hemolysis. - The blood was obtained from rats by cardiac puncture and collected in heparinized tubes. Erythrocytes were separated from plasma and the buffy coat was washed three times with 10 volumes of 0.15 $\mathrm{mol} \mathrm{L}^{-1} \mathrm{NaCl}$. During the last wash, the erythrocytes were centrifuged at $2500 \mathrm{rpm}$ for 10 min to obtain a constantly packed cell preparation. Erythrocyte hemolysis was mediated by peroxyl radicals in this assay system (17). A $10 \%$ suspension of erythrocytes in phosphate buffered saline $\mathrm{pH} 7.4$ (PBS) was added to the same volume of $200 \mathrm{mmol} \mathrm{L}^{-1}$ AAPH solution in PBS containing samples to be tested ( $50 \mu \mathrm{L}$ of $2 \mathrm{mmol} \mathrm{L}^{-1}$ solution). The reaction mixture was shaken gently while being incubated at $37^{\circ} \mathrm{C}$ for $2 \mathrm{~h}$. The reaction mixture was then removed, diluted with eight volumes of PBS and centrifuged at $1500 \times g$ for $10 \mathrm{~min}$. The absorbance of the supernatant was read at $540 \mathrm{~nm}$. Similarly, the reaction mixture was treated with 8 volumes of distilled water to achieve complete hemolysis, and the absorbance of the supernatant obtained after centrifugation was measured at $540 \mathrm{~nm}$. The data for hemolysis percentage was expressed as mean \pm standard deviation. L-ascorbic acid was used as a positive control.

Antioxidant activity screening via ABTS method. - For each of the investigated compounds, $2 \mathrm{~mL}$ of ABTS solution $\left(60 \mu \mathrm{mol} \mathrm{L}^{-1}\right)$ was added to $3 \mathrm{~mL} \mathrm{MnO}_{2}$ solution $(\gamma=25$ $\left.\mathrm{mg} \mathrm{mL}^{-1}\right)$, all prepared in aqueous phosphate buffer $\left(\mathrm{pH} 7,0.1 \mathrm{~mol} \mathrm{~L}^{-1}\right)$. The mixture was shaken, centrifuged, filtered and the absorbance of the resulting green-blue solution (ABTS radical solution) at $734 \mathrm{~nm}$ was adjusted to approx. 0.5. Then, $50 \mu \mathrm{L}$ of $2 \mathrm{mmol}$ $\left.\mathrm{L}^{-1}\right)$ solution of the test compound in spectroscopic grade $\mathrm{MeOH} /$ phosphate buffer $(1: 1)$ 
A. A. Abu-Hashem et al.: Design and synthesis of novel thiophenecarbohydrazide, thienopyrazole and thienopyrimidine derivatives as antioxidant and antitumor agents, Acta Pharm. 60 (2010) 311-323.

was added. The absorbance was measured and the reduction in color intensity was expressed as inhibition percentage. L-ascorbic acid was used as standard antioxidant (positive control). Blank sample was run without ABTS and using $\mathrm{MeOH} /$ phosphate buffer (1:1) instead of a sample. Negative control was run with ABTS and $\mathrm{MeOH} /$ phosphate buffer (1:1) instead of test compound (18-20).

Bleomycin-dependent DNA damage. - The assay was done according to Aeschlach (21) with minor modifications. The reaction mixture $(0.5 \mathrm{~mL})$ contained calf thymus DNA $\left(0.5 \mathrm{mg} \mathrm{mL}^{-1}\right)$, bleomycin sulfate $\left(0.05 \mathrm{mg} \mathrm{mL}^{-1}\right), \mathrm{MgCl}_{2}\left(5 \mathrm{mmol} \mathrm{L}^{-1}\right), \mathrm{FeCl}_{3}(50 \mu \mathrm{mol}$ $\left.\mathrm{L}^{-1}\right)$ and the sample to be tested ( $50 \mu \mathrm{L}$ of $2 \mathrm{mmol} \mathrm{L}^{-1}$ solution). L-ascorbic acid was used as a positive control. The mixture was incubated at $37^{\circ} \mathrm{C}$ for $1 \mathrm{~h}$. The reaction was terminated by addition $0.05 \mathrm{~mL}$ EDTA $\left(0.1 \mathrm{~mol} \mathrm{~L}^{-1}\right)$. The color was developed by adding 0.5 $\mathrm{mL}$ TBA $(1 \%, m / V)$ and $0.5 \mathrm{~mL} \mathrm{HCl}(25 \%, V / V)$ followed by heating at $37{ }^{\circ} \mathrm{C}$ for 15 min. After centrifugation, the extent of DNA damage was measured by the increase in absorbance at $532 \mathrm{~nm}$.

Antitumor activity using Ehrlich ascites in vitro assay. - Tested compounds were prepared in a concentration of $25 \mathrm{mg} \mathrm{mL}^{-1}$ in DMSO. Ascites fluid from the peritoneal cavity of a diseased mouse (containing Ehrlich cells) was aseptically aspirated. The cells were grown partly floating and partly attached in a suspension culture in RPMI 1640 medium, supplemented with $10 \%$ fetal bovine serum. They were maintained at $37^{\circ} \mathrm{C}$ in a humidified atmosphere with $5 \% \mathrm{CO}_{2}$ for $2 \mathrm{~h}$. The viability of the cells was determined by microscopical examination using a hemocytometer and using trypan blue stain (stains only dead cells) (22).

\section{RESULTS AND DISCUSSION}

\section{Chemistry}

First, aminothiophene (1) was prepared by the reaction of acetylacetone with ethylcyanoacetate and sulfur in the presence of diethylamine following the Gewald procedure (23). ${ }^{1} \mathrm{H}$ NMR spectrum of 1 showed, beside the two signals of ester moiety, a new broad singlet at $\delta 6.66 \mathrm{ppm}$ characteristic of the amino group. Moreover, the mass spectra showed an ion peak $m / z 227\left[\mathrm{M}^{+}\right]$, which was in accord with the calculated molecular mass for $\mathrm{C}_{10} \mathrm{H}_{13} \mathrm{NOS}$.

Hydrazide 2 was achieved after refluxing compound 1 with hydrazine hydrate in ethanol. ${ }^{1} \mathrm{H}$ NMR spectrum of 2 showed the absence of the two signals of ester moiety detected in parent $\mathbf{1}$ along with other protons at their expected locations.

Hydrazide 2 reacted with 2,4-diketones, namely, pentane-2,4-dione or 3-chloropentane-2,4-dione to afford $3 \mathbf{a}$ and $3 \mathbf{b}$, respectively. The ${ }^{1} \mathrm{H}$ NMR spectrum of $3 \mathbf{a}$ revealed new signals at $\delta 2.10 \mathrm{ppm}$ assignable to $2 \mathrm{CH}_{3}$ groups, $\delta 7.96 \mathrm{ppm}$ for pyrazole proton and $\delta 12.51 \mathrm{ppm}$ for $\mathrm{NH}_{2}$ (as $\mathrm{D}_{2} \mathrm{O}$ exchangeable).

Also, hydrazide 2 reacted with diethylmalonate affording pyrazolidine-3,5-dione derivative 4 . The ${ }^{1} \mathrm{H}$ NMR spectrum showed the absence of the hydrazo signal and the presence of new signals at $\delta 2.78 \mathrm{ppm}$ for $\mathrm{CH}_{2}$ group and $\delta 12.32 \mathrm{ppm}$ corresponding to (as a $\mathrm{D}_{2} \mathrm{O}$ exchangeable $\mathrm{NH}$ proton) along with other protons detected in parent 4 . 


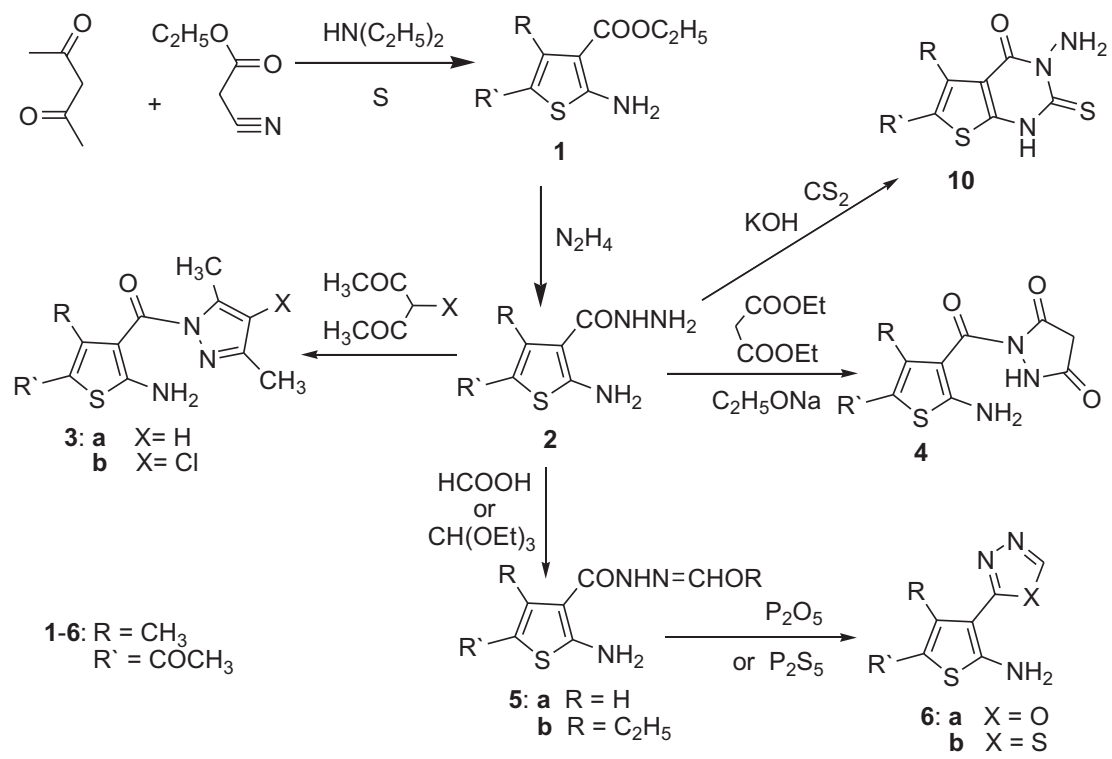

Scheme 1

Treatment of 2 with formic acid or triethylorthoformate afforded $\mathbf{5 a}$ and $\mathbf{5 b}$, respectively, in fairly good yields. ${ }^{1} \mathrm{H}$ NMR spectrum of 5 a showed signals at $\delta 8.44 \mathrm{ppm}$ for $\mathrm{CH}$ proton, and $\delta 11.55 \mathrm{ppm}$ (as a $\mathrm{D}_{2} \mathrm{O}$ exchangeable $\mathrm{OH}$ proton), while the ${ }^{1} \mathrm{H}$ NMR spectrum of $5 \mathbf{b}$ showed new signals at $\delta 1.31,4.32 \mathrm{ppm}$ for $\mathrm{CH}_{2} \mathrm{CH}_{3}$ moiety and $\delta 6.67$ ppm for $\mathrm{CH}$ proton.

Moreover, compounds $5 \mathbf{a}$ and $\mathbf{5 b}$ undergo cyclization when treated with $\mathrm{P}_{2} \mathrm{O}_{5}$ and $\mathrm{P}_{2} \mathrm{~S}_{5}$, to yield thienyloxadiazole (6a) and thienylthiadiazole (6b) derivatives, respectively. The ${ }^{1} \mathrm{H}$ NMR spectrum of $\mathbf{6 a}$ and $\mathbf{6 b}$ showed signals at $\delta 7.12 \mathrm{ppm}$ characteristic of the oxadiazole proton of $\mathbf{6 a}$ and $\delta 7.85 \mathrm{ppm}$ for thiadiazole proton of $\mathbf{6 b}$ beside the other expected signals characteristic of methyl, acetyl and amino groups.

Hydrazide 2 reacted with carbon disulphide in ethanolic potassium hydroxide to afford thienopyrimidinone derivative (10). ${ }^{1} \mathrm{H}$ NMR spectrum showed signals at $\delta 6.12 \mathrm{ppm}$ for $\mathrm{NH}_{2}$ and $\delta 7.44 \mathrm{ppm}$ for $\mathrm{NH}$ proton (as $\mathrm{D}_{2} \mathrm{O}$ exchangeable) beside the signals characteristic of acetyl and methyl groups; moreover, the mass spectrum revealed an ion peak at $m / z 255\left[\mathrm{M}^{+}\right]$, which was in accord with the calculated molecular mass $\mathrm{C}_{9} \mathrm{H}_{9} \mathrm{~N}_{3} \mathrm{O}_{2} \mathrm{~S}_{2}$ (Scheme 1).

Compound 1, when treated with acetic anhydride, afforded 2-thienylacetamide derivative (7). Moreover, when compound 7 was allowed to react with hydrazine hydrate, it yielded aminothienopyrimidinone derivative (8). ${ }^{1} \mathrm{H}$ NMR of 8 revealed signals at $\delta$ $1.97 \mathrm{ppm}$ for $\mathrm{CH}_{3}$ and $7.33 \mathrm{ppm}\left(\mathrm{D}_{2} \mathrm{O}\right.$ exchangeable $\mathrm{NH}_{2}$ protons) with a lack of peaks attributed to the ester protons detected in the parent compound 7.

When compound 1 was stirred with a mixture of carbon disulphide, sodium hydroxide in dimethylsulphoxide and dimethylsulphate, according to the Alagarsamy proce- 
A. A. Abu-Hashem et al.: Design and synthesis of novel thiophenecarbohydrazide, thienopyrazole and thienopyrimidine derivatives as antioxidant and antitumor agents, Acta Pharm. 60 (2010) 311-323.

Table I. Physical and analytical data of newly synthesized compounds

\begin{tabular}{|c|c|c|c|c|c|c|}
\hline \multirow{2}{*}{$\begin{array}{l}\text { Compd. } \\
\text { No. }\end{array}$} & \multirow{2}{*}{ Yield (\%) } & \multirow{2}{*}{ M.p. $\left({ }^{\circ} \mathrm{C}\right)$} & \multirow{2}{*}{$\begin{array}{c}\text { Molecular } \\
\text { formula }\left(M_{\mathrm{r}}\right)\end{array}$} & \multicolumn{3}{|c|}{$\begin{array}{l}\text { Microanalytical analysis } \\
\text { Calcd./found (\%) }\end{array}$} \\
\hline & & & & C & $\mathrm{H}$ & $\mathrm{N}$ \\
\hline \multirow{2}{*}{1} & \multirow{2}{*}{90} & \multirow{2}{*}{$160-162$} & $\mathrm{C}_{10} \mathrm{H}_{13} \mathrm{NO}_{3} \mathrm{~S}$ & 52.85 & 5.77 & 6.16 \\
\hline & & & $(227.28)$ & 52.82 & 5.71 & 6.15 \\
\hline \multirow{2}{*}{2} & \multirow{2}{*}{85} & \multirow{2}{*}{$110-112$} & $\mathrm{C}_{8} \mathrm{H}_{11} \mathrm{~N}_{3} \mathrm{O}_{2} \mathrm{~S}$ & 45.06 & 5.20 & 19.70 \\
\hline & & & (213.26) & 45.10 & 5.15 & 19.70 \\
\hline \multirow{2}{*}{$3 a$} & \multirow{2}{*}{75} & \multirow{2}{*}{ 140-142 } & $\mathrm{C}_{13} \mathrm{H}_{15} \mathrm{~N}_{3} \mathrm{O}_{2} \mathrm{~S}$ & 56.30 & 5.45 & 15.15 \\
\hline & & & $(277.34)$ & 56.32 & 5.40 & 15.10 \\
\hline \multirow{2}{*}{$3 b$} & \multirow{2}{*}{70} & \multirow{2}{*}{ 290-292 } & $\mathrm{C}_{13} \mathrm{H}_{14} \mathrm{ClN}_{3} \mathrm{O}_{2} \mathrm{~S}$ & 50.08 & 4.53 & 13.48 \\
\hline & & & $(311.79)$ & 50.12 & 4.50 & 13.45 \\
\hline \multirow{2}{*}{4} & \multirow{2}{*}{75} & \multirow{2}{*}{ 137-139 } & $\mathrm{C}_{11} \mathrm{H}_{11} \mathrm{~N}_{3} \mathrm{O}_{4} \mathrm{~S}$ & 46.97 & 3.94 & 14.94 \\
\hline & & & $(281.29)$ & 46.95 & 3.90 & 14.90 \\
\hline \multirow{2}{*}{$5 a$} & \multirow{2}{*}{78} & \multirow{2}{*}{$123-125$} & $\mathrm{C}_{9} \mathrm{H}_{11} \mathrm{~N}_{3} \mathrm{O}_{3} \mathrm{~S}$ & 44.80 & 4.60 & 17.42 \\
\hline & & & $(241.27)$ & 44.83 & 4.62 & 17.40 \\
\hline \multirow{2}{*}{$5 b$} & \multirow{2}{*}{75} & \multirow{2}{*}{$131-133$} & $\mathrm{C}_{11} \mathrm{H}_{15} \mathrm{~N}_{3} \mathrm{O}_{3} \mathrm{~S}$ & 49.06 & 5.61 & 15.60 \\
\hline & & & (269.32) & 49.08 & 5.60 & 15.63 \\
\hline \multirow{2}{*}{$6 a$} & \multirow{2}{*}{70} & \multirow{2}{*}{$138-140$} & $\mathrm{C}_{9} \mathrm{H}_{9} \mathrm{~N}_{3} \mathrm{O}_{2} \mathrm{~S}$ & 48.42 & 4.06 & 18.82 \\
\hline & & & $(223.25)$ & 48.40 & 4.03 & 18.80 \\
\hline \multirow{2}{*}{$6 b$} & 60 & ii & $\mathrm{C}_{9} \mathrm{H}_{9} \mathrm{~N}_{3} \mathrm{OS}_{2}$ & 45.17 & 3.79 & 17.56 \\
\hline & 60 & O1l & $(239.32)$ & 45.14 & 3.75 & 17.53 \\
\hline 7 & 90 & $146-148$ & $\mathrm{C}_{12} \mathrm{H}_{15} \mathrm{NO}_{4} \mathrm{~S}$ & 53.52 & 5.61 & 5.20 \\
\hline 7 & 90 & $146-148$ & $(269.32)$ & 53.50 & 5.60 & 5.23 \\
\hline 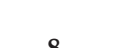 & 85 & $272 \quad 275$ & $\mathrm{C}_{10} \mathrm{H}_{11} \mathrm{~N}_{3} \mathrm{OS}$ & 54.28 & 5.01 & 18.99 \\
\hline 8 & 85 & $273-275$ & $(221.28)$ & 54.25 & 5.03 & 18.95 \\
\hline 9 & 80 & 198-200 & $\mathrm{C}_{12} \mathrm{H}_{15} \mathrm{NO}_{3} \mathrm{~S}_{3}$ & 45.40 & 4.76 & 4.41 \\
\hline 9 & 80 & $198-200$ & $(317.45)$ & 45.43 & 4.72 & 4.40 \\
\hline 10 & 75 & $330-332$ & $\mathrm{C}_{9} \mathrm{H}_{9} \mathrm{~N}_{3} \mathrm{O}_{2} \mathrm{~S}_{2}$ & 42.34 & 3.55 & 16.46 \\
\hline 10 & 75 & $330-332$ & $(255.32)$ & 42.30 & 3.50 & 16.42 \\
\hline 11 & 80 & 201-203 & $\mathrm{C}_{11} \mathrm{H}_{14} \mathrm{~N}_{2} \mathrm{O}_{3} \mathrm{~S}_{2}$ & 46.14 & 4.93 & 9.78 \\
\hline 11 & 80 & & $(286.37)$ & 46.10 & 4.90 & 9.75 \\
\hline 12 & 85 & 220241 & $\mathrm{C}_{9} \mathrm{H}_{8} \mathrm{~N}_{2} \mathrm{O}_{2} \mathrm{~S}_{2}$ & 44.98 & 3.36 & 11.66 \\
\hline 12 & 83 & $239-241$ & $(240.30)$ & 44.95 & 3.30 & 11.62 \\
\hline
\end{tabular}

dure (24), it afforded 9. ${ }^{1} \mathrm{H}$ NMR spectrum of 9 showed the absence of the amino signal and appearance of new signals at $\delta 3.85 \mathrm{ppm}$ for $\mathrm{SCH}_{3}$ and $\delta 11.72 \mathrm{ppm}$ (as a $\mathrm{D}_{2} \mathrm{O}$ exchangeable $\mathrm{NH}$ proton). It is worth mentioning that compound 9 cyclized with hydrazine hydrate to yield 10.

Finally, the reaction of compound 1 with potassium thiocyanate afforded the formation of 2-thioureidothiophene derivative (11). Moreover, when compound $\mathbf{1 1}$ was refluxed in sodium ethoxide, it underwent self-cyclization to yield 2-thioxothienopyrimidi- 
A. A. Abu-Hashem et al.: Design and synthesis of novel thiophenecarbohydrazide, thienopyrazole and thienopyrimidine derivatives as antioxidant and antitumor agents, Acta Pharm. 60 (2010) 311-323.

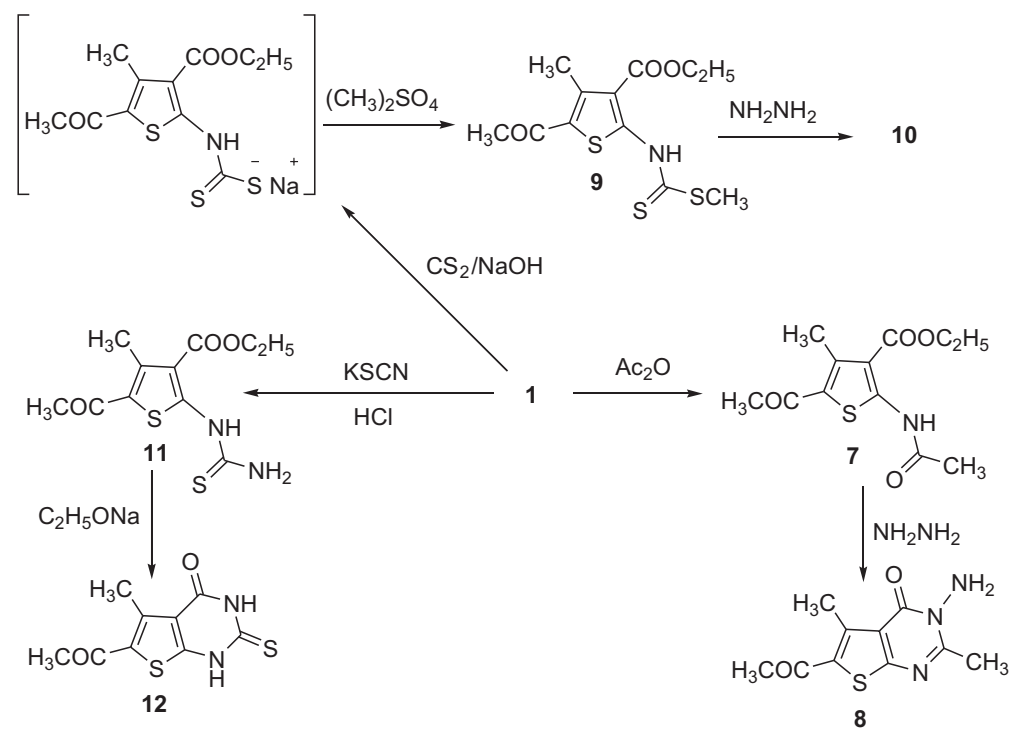

Scheme 2

none derivative (12). The ${ }^{1} \mathrm{H}$ NMR of 12 revealed signals at $\delta 11.90,12.29 \mathrm{ppm}\left(\mathrm{as}_{2} \mathrm{O}\right.$ exchangeable $2 \mathrm{NH}$ protons) with a lack of peaks attributed to the ester protons detected in the parent compound $\mathbf{1 1}$ (Scheme 2).

\section{Antioxidant activity}

All compounds were tested for antioxidant activity as reflected in the ability to inhibit lipid peroxidation in rat brain and kidney homogenates and the rate of erythrocyte hemolysis. Pro-oxidant activities of the formed compounds were assayed via their effects on bleomycin-induced DNA damage. Compounds $\mathbf{1 0}$ and $\mathbf{1 2}$ manifested potent antioxidative activity in the lipid peroxidation assay but no inhibitory activity in the hemolysis assay. On the other hand, compounds $3 a, 4,5 a, 5 b, 6 a, 6 b, 8,10$ and 12 exhibited significant antioxidant activity and protected the DNA from damage (Table III).

\section{Antitumor activity using the in vitro Ehrlich used ascites assay}

The newly synthesized compounds were screened for their antitumor activity. Viability of the cells used in control experiments exceeded $95 \%$. Compound 6a proved to have the highest cytotoxic activity (83.1\%) followed by compounds 8, 10, 12 (79.9-77.2 \%) and $11(67.9 \%)$. The other tested compounds showed very weak activity (45.1-4.9\%) (Table IV). 
A. A. Abu-Hashem et al.: Design and synthesis of novel thiophenecarbohydrazide, thienopyrazole and thienopyrimidine derivatives as antioxidant and antitumor agents, Acta Pharm. 60 (2010) 311-323.

Table II. Mass, IR and ${ }^{1} \mathrm{H}$ NMR spectral data of newly synthesized compounds

\begin{tabular}{|c|c|c|c|}
\hline $\begin{array}{l}\text { Compd. } \\
\text { No. }\end{array}$ & $\begin{array}{c}\text { Mass } m / z \\
\text { (abundance, \%) }\end{array}$ & $\begin{array}{l}\text { IR }(\mathrm{KBr}) \\
\left(v, \mathrm{~cm}^{-1}\right)\end{array}$ & ${ }^{1} \mathrm{H}$ NMR $\left(\right.$ DMSO-d $\left.{ }_{6}\right), \delta(p p m)$ \\
\hline 1 & $\begin{array}{l}227\left[\mathrm{M}^{+}\right] \\
\quad(35)\end{array}$ & $\begin{array}{c}3425\left(\mathrm{NH}_{2}\right) \\
1700,1720(2 \mathrm{CO})\end{array}$ & $\begin{array}{l}1.29\left(\mathrm{t}, 3 \mathrm{H}, \mathrm{CH}_{3}\right), 2.24\left(\mathrm{~s}, 3 \mathrm{H}, \mathrm{CH}_{3}\right), 2.59(\mathrm{~s}, 3 \mathrm{H}, \\
\left.\mathrm{COCH}_{3}\right), 4.29\left(\mathrm{q}, 2 \mathrm{H}, \mathrm{CH}_{2}\right), 6.66 \text { (br.s, } 2 \mathrm{H}, \mathrm{NH}_{2} \\
\mathrm{D}_{2} \mathrm{O} \text { exchangeable) }\end{array}$ \\
\hline 2 & $\begin{array}{l}213\left[\mathrm{M}^{+}\right] \\
(100)\end{array}$ & $\begin{array}{rl}3420 & 3355(\mathrm{NH}, \\
& \left.\mathrm{NH}_{2}\right) \\
1700, & 1690(2 \mathrm{CO})\end{array}$ & $\begin{array}{l}2.25\left(\mathrm{~s}, 3 \mathrm{H}, \mathrm{CH}_{3}\right), 2.58\left(\mathrm{~s}, 3 \mathrm{H}, \mathrm{COCH}_{3}\right), 6.12 \text { (br.s, } 2 \mathrm{H} \text {, } \\
\mathrm{NH}_{2}, \mathrm{D}_{2} \mathrm{O} \text { exchangeable), } 7.33 \text { (br.s, } 2 \mathrm{H}, \mathrm{NH}_{2}, \mathrm{D}_{2} \mathrm{O} \\
\text { exchangeable), } 8.16\left(\mathrm{~s}, 1 \mathrm{H}, \mathrm{NH}, \mathrm{D}_{2} \mathrm{O} \text { exchangeable) }\right.\end{array}$ \\
\hline $3 a$ & $\begin{array}{l}277\left[\mathrm{M}^{+}\right] \\
\quad(100)\end{array}$ & $\begin{array}{c}3410\left(\mathrm{NH}_{2}\right) \\
1705,1685(2 \mathrm{CO})\end{array}$ & $\begin{array}{l}2.10\left(\mathrm{~s}, 6 \mathrm{H}, 2 \mathrm{CH}_{3}\right), 2.23\left(\mathrm{~s}, 3 \mathrm{H}, \mathrm{CH}_{3}\right), 2.57(\mathrm{~s}, 3 \mathrm{H}, \\
\left.\mathrm{CO} \mathrm{CH} \mathrm{CH}_{3}\right), 7.96(\mathrm{~s}, 1 \mathrm{H}, \text { pyrazole proton}), 12.51 \\
\text { (br.s, } 2 \mathrm{H}, \mathrm{NH}_{2}, \mathrm{D}_{2} \mathrm{O} \text { exchangeable) }\end{array}$ \\
\hline $3 b$ & $\begin{array}{l}311\left[\mathrm{M}^{+}\right] \\
\quad(40)\end{array}$ & $\begin{array}{c}3415\left(\mathrm{NH}_{2}\right) \\
1706,1689(2 \mathrm{CO})\end{array}$ & $\begin{array}{l}2.07\left(\mathrm{~s}, 6 \mathrm{H}, 2 \mathrm{CH}_{3}\right), 2.31\left(\mathrm{~s}, 3 \mathrm{H}, \mathrm{CH}_{3}\right), 2.56(\mathrm{~s}, 3 \mathrm{H}, \\
\left.\mathrm{COCH}_{3}\right), 12.53 \text { (br.s, } 2 \mathrm{H}, \mathrm{NH}_{2}, \mathrm{D}_{2} \mathrm{O} \text { exchangeable) }\end{array}$ \\
\hline 4 & $\begin{array}{l}281\left[\mathrm{M}^{+}\right] \\
\quad(25)\end{array}$ & $\begin{array}{l}3410(\mathrm{NH}) \\
1700,1690,1685 \\
1679(4 \mathrm{CO})\end{array}$ & $\begin{array}{l}2.24\left(\mathrm{~s}, 3 \mathrm{H}, \mathrm{CH}_{3}\right), 2.58\left(\mathrm{~s}, 3 \mathrm{H}, \mathrm{COCH}_{3}\right), 2.78(\mathrm{~s}, \\
\left.2 \mathrm{H}, \mathrm{CH}_{2}\right), 9.35 \text { (br.s, } 2 \mathrm{H}, \mathrm{NH}_{2}, \mathrm{D}_{2} \mathrm{O} \text { exchangeable), } \\
12.32\left(\mathrm{~s}, 1 \mathrm{H}, \mathrm{NH}, \mathrm{D}_{2} \mathrm{O} \text { exchangeable }\right)\end{array}$ \\
\hline $5 a$ & $\begin{array}{l}241\left[\mathrm{M}^{+}\right] \\
\quad(45)\end{array}$ & $\begin{array}{c}3420(\mathrm{NH}) \\
1710,1685(2 \mathrm{CO})\end{array}$ & $\begin{array}{l}2.25\left(\mathrm{~s}, 3 \mathrm{H}, \mathrm{CH}_{3}\right), 2.59\left(\mathrm{~s}, 3 \mathrm{H}, \mathrm{COCH}_{3}\right), 8.44(\mathrm{~s}, \\
1 \mathrm{H}, \text { azomethine } \mathrm{CH} \text { proton), } 8.59\left(\mathrm{br} . \mathrm{s}, 2 \mathrm{H}, \mathrm{NH}_{2}\right. \\
\mathrm{D}_{2} \mathrm{O} \text { exchangeable), } 11.31\left(\mathrm{~s}, 1 \mathrm{H}, \mathrm{NH}, \mathrm{D}_{2} \mathrm{O} \text { ex- }\right. \\
\text { changeable), } 11.55\left(\mathrm{~s}, 1 \mathrm{H}, \mathrm{OH}, \mathrm{D}_{2} \mathrm{O} \text { exchangeable) }\right.\end{array}$ \\
\hline $5 b$ & $\begin{array}{l}269\left[\mathrm{M}^{+}\right] \\
\quad(40)\end{array}$ & $\begin{array}{c}3410(\mathrm{NH}) \\
1700,1680,(2 \mathrm{CO})\end{array}$ & $\begin{array}{l}1.31\left(\mathrm{t}, 3 \mathrm{H}, \mathrm{CH}_{3}\right), 2.26\left(\mathrm{~s}, 3 \mathrm{H}, \mathrm{CH}_{3}\right), 2.60(\mathrm{~s}, 3 \mathrm{H}, \\
\left.\mathrm{COCH}_{3}\right), 4.32\left(\mathrm{q}, 2 \mathrm{H}, \mathrm{CH}_{2}\right), 6.67(\mathrm{~s}, 1 \mathrm{H}, \text { azome- } \\
\text { thine } \mathrm{CH} \text { proton }), 8.49\left(\mathrm{br} . \mathrm{s}, 2 \mathrm{H}, \mathrm{NH}_{2}, \mathrm{D}_{2} \mathrm{O} \text { ex- }\right. \\
\text { changeable }), 11.10\left(\mathrm{~s}, 1 \mathrm{H}, \mathrm{NH}, \mathrm{D}_{2} \mathrm{O} \text { exchangeable }\right)\end{array}$ \\
\hline $6 a$ & $\begin{array}{l}223\left[\mathrm{M}^{+}\right] \\
\quad(71)\end{array}$ & $\begin{array}{c}3395\left(\mathrm{NH}_{2}\right) \\
1700(\mathrm{CO})\end{array}$ & $\begin{array}{l}2.24\left(\mathrm{~s}, 3 \mathrm{H}, \mathrm{CH}_{3}\right), 2.58\left(\mathrm{~s}, 3 \mathrm{H}, \mathrm{COCH}_{3}\right), 7.12 \\
\left(\mathrm{~s}, 1 \mathrm{H} \text {, oxadiazole proton), } 8.16 \text { (br.s, } 2 \mathrm{H}, \mathrm{NH}_{2}\right. \\
\mathrm{D}_{2} \mathrm{O} \text { exchangeable) }\end{array}$ \\
\hline $6 b$ & $\begin{array}{l}239\left[\mathrm{M}^{+}\right] \\
\quad(100)\end{array}$ & $\begin{array}{l}3398\left(\mathrm{NH}_{2}\right) \\
1705(\mathrm{CO})\end{array}$ & $\begin{array}{l}2.27\left(\mathrm{~s}, 3 \mathrm{H}, \mathrm{CH}_{3}\right), 2.60\left(\mathrm{~s}, 3 \mathrm{H}, \mathrm{COCH}_{3}\right), 7.85 \\
\left(\mathrm{~s}, 1 \mathrm{H} \text {, thiadiazole proton), } 8.90 \text { (br.s, } 2 \mathrm{H}, \mathrm{NH}_{2}\right. \\
\mathrm{D}_{2} \mathrm{O} \text { exchangeable) }\end{array}$ \\
\hline 7 & $\begin{array}{l}269\left[\mathrm{M}^{+}\right] \\
\quad(69)\end{array}$ & $\begin{array}{l}3420(\mathrm{NH}) \\
1720,1690,1685 \\
(3 \mathrm{CO})\end{array}$ & $\begin{array}{l}1.28\left(\mathrm{t}, 3 \mathrm{H}, \mathrm{CH}_{3}\right), 2.24\left(\mathrm{~s}, 3 \mathrm{H}, \mathrm{CH}_{3}\right) 2.44(\mathrm{~s}, 3 \mathrm{H}, \\
\left.\mathrm{COCH}_{3}\right), 2.59\left(\mathrm{~s}, 3 \mathrm{H}, \mathrm{COCH}_{3}\right), 4.31\left(\mathrm{q}, 2 \mathrm{H}, \mathrm{CH}_{2}\right), \\
11.10\left(\mathrm{~s}, 1 \mathrm{H}, \mathrm{NH}, \mathrm{D}_{2} \mathrm{O} \text { exchangeable }\right)\end{array}$ \\
\hline 8 & $\begin{array}{l}237\left[\mathrm{M}^{+}\right] \\
\quad(92)\end{array}$ & $\begin{array}{c}3415\left(\mathrm{NH}_{2}\right) \\
1705,1680(2 \mathrm{CO})\end{array}$ & $\begin{array}{l}1.97\left(\mathrm{~s}, 3 \mathrm{H}, \mathrm{CH}_{3}\right), 2.23\left(\mathrm{~s}, 3 \mathrm{H}, \mathrm{CH}_{3}\right), 2.58(\mathrm{~s}, 3 \mathrm{H}, \\
\left.\mathrm{COCH}_{3}\right) 7.33 \text { (br.s, } 2 \mathrm{H}, \mathrm{NH}_{2}, \mathrm{D}_{2} \mathrm{O} \text { exchangeable) }\end{array}$ \\
\hline 9 & $\begin{array}{l}317\left[\mathrm{M}^{+}\right] \\
\quad(64)\end{array}$ & $\begin{array}{c}3300(\mathrm{NH}) \\
1705,1725(2 \mathrm{CO})\end{array}$ & $\begin{array}{l}1.28\left(\mathrm{t}, 3 \mathrm{H}, \mathrm{CH}_{3}\right), 2.25\left(\mathrm{~s}, 3 \mathrm{H}, \mathrm{CH}_{3}\right), 2.58(\mathrm{~s}, 3 \mathrm{H}, \\
\left.\mathrm{COCH}_{3}\right), 3.85\left(\mathrm{~s}, 3 \mathrm{H}, \mathrm{SCH}_{3}\right) 4.28\left(\mathrm{q}, 2 \mathrm{H}, \mathrm{CH}_{2}\right) \\
11.72\left(\mathrm{~s}, 1 \mathrm{H}, \mathrm{NH}, \mathrm{D}_{2} \mathrm{O} \text { exchangeable }\right)\end{array}$ \\
\hline 10 & $\begin{array}{l}255\left[\mathrm{M}^{+}\right] \\
\quad(88)\end{array}$ & $\begin{array}{c}3250\left(\mathrm{NH}_{2}\right) \\
1700,1685(2 \mathrm{CO})\end{array}$ & $\begin{array}{l}2.10\left(\mathrm{~s}, 3 \mathrm{H}, \mathrm{CH}_{3}\right), 3.21\left(\mathrm{~s}, 3 \mathrm{H}, \mathrm{COCH}_{3}\right), 6.12 \text { (br.s, } \\
2 \mathrm{H}, \mathrm{NH}_{2}, \mathrm{D}_{2} \mathrm{O} \text { exchangeable), } 7.44(\mathrm{~s}, 1 \mathrm{H}, \mathrm{NH} \\
\mathrm{D}_{2} \mathrm{O} \text { exchangeable) }\end{array}$ \\
\hline 11 & $\begin{array}{l}286\left[\mathrm{M}^{+}\right] \\
\quad(72)\end{array}$ & $\begin{aligned} 3380, & 3260(\mathrm{NH}, \\
& \left.\mathrm{NH}_{2}\right) \\
1700, & 1720(2 \mathrm{CO})\end{aligned}$ & $\begin{array}{l}1.29\left(\mathrm{t}, 3 \mathrm{H}, \mathrm{CH}_{3}\right), 2.24\left(\mathrm{~s}, 3 \mathrm{H}, \mathrm{CH}_{3}\right), 2.59(\mathrm{~s}, 3 \mathrm{H}, \\
\left.\mathrm{COCH}_{3}\right), 4.32\left(\mathrm{q}, 2 \mathrm{H}, \mathrm{CH}_{2}\right), 6.84\left(\text { br.s, } 2 \mathrm{H}, \mathrm{NH}_{2}, \mathrm{D}_{2} \mathrm{O}\right. \\
\text { exchangeable }), 10.97\left(\mathrm{~s}, 1 \mathrm{H}, \mathrm{NH}, \mathrm{D}_{2} \mathrm{O} \text { exchangeable }\right)\end{array}$ \\
\hline 12 & $\begin{array}{c}240\left[\mathrm{M}^{+}\right] \\
(83)\end{array}$ & $\begin{array}{l}3390,3385(2 \mathrm{NH}) \\
1705,1680(2 \mathrm{CO})\end{array}$ & $\begin{array}{l}2.23\left(\mathrm{~s}, 3 \mathrm{H}, \mathrm{CH}_{3}\right), 2.95\left(\mathrm{~s}, 3 \mathrm{H}, \mathrm{COCH}_{3}\right), 11.90 \\
\left(\mathrm{~s}, 1 \mathrm{H}, \mathrm{NH}, \mathrm{D}_{2} \mathrm{O} \text { exchangeable) } 12.29(\mathrm{~s}, 1 \mathrm{H}, \mathrm{NH},\right. \\
\left.\mathrm{D}_{2} \mathrm{O} \text { exchangeable }\right)\end{array}$ \\
\hline
\end{tabular}


A. A. Abu-Hashem et al.: Design and synthesis of novel thiophenecarbohydrazide, thienopyrazole and thienopyrimidine derivatives as antioxidant and antitumor agents, Acta Pharm. 60 (2010) 311-323.

Table III. Antioxidant activity of the prepared compounds

\begin{tabular}{ccc}
\hline $\begin{array}{c}\text { Compd. } \\
\text { No. }^{\text {a }}\end{array}$ & $\begin{array}{c}\text { ABTS inhibition } \\
(\%)\end{array}$ & $\begin{array}{c}\text { Erythrocyte } \\
\text { hemolysis }(\%)\end{array}$ \\
\hline L-ascorbic acid & 88.6 & 0.9 \\
$\mathbf{1}$ & 20.2 & 7.5 \\
$\mathbf{2}$ & 24.3 & 6.4 \\
$\mathbf{3 a}$ & 70.8 & 1.7 \\
$\mathbf{3 b}$ & 44.4 & 4.8 \\
$\mathbf{4}$ & 65.9 & 1.9 \\
$\mathbf{5 a}$ & 60.9 & 2.5 \\
$\mathbf{5 b}$ & 55.3 & 2.8 \\
$\mathbf{6 a}$ & 80.4 & 1.1 \\
$\mathbf{6 b}$ & 79.2 & 1.4 \\
$\mathbf{7}$ & 50.3 & 3.5 \\
$\mathbf{8}$ & 72.9 & 1.5 \\
$\mathbf{9}$ & 48.2 & 3.7 \\
$\mathbf{1 0}$ & 88.6 & 0.9 \\
$\mathbf{1 1}$ & 35.6 & 5.6 \\
$\mathbf{1 2}$ & 83.3 & 1.0 \\
\hline
\end{tabular}

a For testing $50 \mu \mathrm{L}$ of $2 \mathrm{mmol} \mathrm{L}-1$ solution in $1 \mathrm{~mL}$ methanol/phosphate buffer $(1: 1, V / V)$ was used.

Table IV. Ehrlich in vitro assay

\begin{tabular}{cc}
\hline Compd. No. ${ }^{\text {a }}$ & Dead cells $(\%)$ \\
\hline $\mathbf{1}$ & 4.9 \\
$\mathbf{2}$ & 45.1 \\
$\mathbf{3 a}$ & 12.0 \\
$\mathbf{3 b}$ & 6.9 \\
$\mathbf{4}$ & 11.4 \\
$\mathbf{5 a}$ & 7.9 \\
$\mathbf{5 b}$ & 15.0 \\
$\mathbf{6 a}$ & 83.1 \\
$\mathbf{6 b}$ & 36.0 \\
$\mathbf{7}$ & 4.9 \\
$\mathbf{8}$ & 79.5 \\
$\mathbf{9}$ & 42.9 \\
$\mathbf{1 0}$ & 79.9 \\
$\mathbf{1 1}$ & 67.9 \\
$\mathbf{1 2}$ & 77.2 \\
5-Florouracil & \\
\hline
\end{tabular}

a $1 \mu \mathrm{g} \mathrm{mL} \mathrm{m}^{-1}$ in DMSO/RPMI-1640 (1:10)

b $25 \mu \mathrm{g} \mathrm{mL}^{-1}$ in DMSO/RPMI-1640 (1:10) 


\section{CONCLUSIONS}

In summary, an interesting thiophene derivatives with substituted diazole, thiadiazole, pyrazole and pyrimidine moieties were synthesized and evaluated for their antioxidant and antitumor activities.

i) Novel thiophene derivatives wit substituted diazole, thiadiazole, pyrazole and pyrimidine moieties possess a potential as antioxidant and antitum agents.

ii) Thienopyrimidinone derivatives were found to be of high antioxidant activity, while thienoxathiazol and thienoxadiazole showed moderate activity compared to thienopyrazole derivatives.

iii) Thienoxadiazole showed the highest cytotoxic activity, higher than thienopyrimidinone and thienylthiourea derivatives.

\section{REFERENCES}

1. K. Dore, S. Dubus, H. A. Ho, I. Levesque, M. Brunette, G. Corbeil, M. Boissinot, G. Boivin, M. Bergeron, D. Boudreau and M. Leclerc, Fluorescent polymeric transducers for the rapid, simple and specific detection of nucleic acids at the zeptomole level, J. Am. Chem. Soc. 126 (2004) 263-287.

2. R. L. Jarvest, I. L. Pinto, S. M. Ashman, C. E. Dabrowski, A.V. Fernandez, L. J. Jennings, P. Lavery and D. G. Taw, Inhibition of herpes proteases and antiviral activity of 2-substituted thieno[2,3-d]oxazinones, Bioog. Med. Chem. Lett. 9 (1999) 443-448.

3. L. Aurelio, H. Figler, L. B. Flynn, J. Linden and J. P. Scammells, 5-Substituted 2-aminothiophenes as A1 adenosine receptor allosteric enhancers, J. Bioorg. Med. Chem. 16 (2008) 1319-1328; DOI: $10.1016 /$ J.BMC.

4. H. Lütjens, A. Zickgraf, H. Figler, J. Linden, R. Olsson and J. P. Scammells, 2-Aminothienopyridazines as novel adenosine $\mathrm{A}_{1}$ receptor allosteric modulators and antagonists, J. Med. Chem. 46 (2003) 1870-1877.

5. K. A. Ghakraborti, B. Gopalakrishnan, M. E. Sobhia and A. Malde, Three D-QSAR studies on thieno $[3,2-d]$ pyrimidines as phosphodiesterase IV inhibitors, Bioorg. Med. Chem. Lett. 13 (2003) $1403-1408$.

6. G. Nikolakopoulos, H. Figler, J. Linden and P. J. Scammells, 2-Aminothiophene-3-carboxylates and carboxamides as adenosine $\mathrm{A}_{1}$ receptor allosteric enhancers, Bioorg. Med. Chem. 14 (2006) 2358-2365; DOI: 10.1016/j.bmc.2005.11.018.

7. S. Sasaki, N. Cho, Y. Nara, M. Harada, S. Endo, N. Suzuki, Sh. Furuya and M. Fujino, Discovery of a thieno [2,3- $d]$ pyrimidine-2,4-dione bearing a $p$-methoxyureidophenyl moiety at the 6-position: a highly potent and orally bioavailable non-peptide antagonist for the human utilizing hormone-releasing hormone receptor, J. Med. Chem. 46 (2003) 113-124.

8. M. O. Nassan, Y. A. Hassan, I. H. Heiba and M. M. Ghorb, Synthesis and reactions of some mercaptoheterocyclic compounds and their radioprotection, Al-Azhar Bull. Sci. 8 (1997) 435-444; ref. Chem. Abstr. 130 (1999) 110174.

9. I. H. Heiba, M. M. Ghorab, E. N. Amin and L. Ramadan, Synthesis of 2-[(5,6,7,8-tetrahydrobenzo $[b]$ thieno[2,3- $d]$ pyrimidin-4-y)thio]- $N$-(4-aryl-3-chloro-2-oxoazetidin-1-yl) acetamides and biochemical screening for radioprotective character, Egypt. J. Biotechnol. 4 (1998) 16-30; ref. Chem. Abstr. 132 (2000) 49937. 
A. A. Abu-Hashem et al.: Design and synthesis of novel thiophenecarbohydrazide, thienopyrazole and thienopyrimidine derivatives as antioxidant and antitumor agents, Acta Pharm. 60 (2010) 311-323.

10. H. N. Hafez and A. B. A. El-Gazzar, Design and synthesis of 3-pyrazolyl-thiophene, thieno [2,3- $d]$ pyrimidines as new bioactive and pharmacological activities, Bioorg. Med. Chem. Lett. 18 (2008) 5222-5227; DOI: 10.1016/j.bmcl.2008.08.071.

11. A. Rosowsky, K. K. N. Chen and M. Lin, 2,4-Diaminothieno [2,3-d] pyrimidines as antifolates and antimalarials, J. Med. Chem. 16 (1973) 191-194.

12. F. Shuichi and S. Nobuhiro, Preventives/Remedies for Alzheimer's Disease, Japan Pat. 0178,780 (Cl. A61K45/00), 25 Oct 2001, JP Appl. 2000/112, 046, 13 Apr 2000; ref. Chem. Abstr. 135 (2001) 313627w.

13. I. Hirotsune, K. Takashi, N. Eisuke, K. Hidetaka, O. Masamichi, T. Takashi and N. Atsushi, Preparation of thienopyrimidine derivatives as antagonists of metabotropic glutamate receptors, Japan Pat. 02 62,803 (Cl. C07D495/04) 15 Aug 2002, Appl. 2001/32, 121; ref. Chem. Abstr. 137 (2002) $169542 \mathrm{~m}$.

14. W. Lichen, R. Jinzhi, L. Baolin, L. Jiaxuan and Y. Jing, Synthesis and cardiac activity of thieno [3,4-d] pyrimidine-2,4-dione derivatives, Journal of Zhongguo Yaoke Daxue Xuebao 29 (1998) 331-335; ref. Chem. Abstr. 130 (1999) 139309d.

15. T. H. Brown, R. J. Ife and C. A. Leach, Preparation and formulation of thienopyrimidine derivatives as antiulcer agents, Eur. Pat. 404356 (Cl.C07D495/0; ref. Chem. Abstr. 115 (1991) 356-361.

16. A. B. A. El-Gazzar, R. A. H. Hussein and N. H. Hafez, Synthesis of 4-substituted pyrido[2,3-d] pyrimidin-4(1H)-one as analgesic and anti-inflammatory agents, Acta Pharm. 57 (2007) 395-411; DOI: $10.2478 / v 10007-007-0032-6$.

17. Y. Morimoto, K. Tanaka, Y. Iwakiri, S. Tokuhiro, S. Fukushima and Y. Takeuchi Erythrocyte hemolysis was mediated by peroxyl radicals in this assay system, Biol. Pharm. Bull. 18 (1995) 1417-1422.

18. E. Lissi, B. Modak, R. Torres, J. Escobar and A. Urzua, Total antioxidant potential of resinous exudates from Heliotropium species, and a comparison of the ABTS and DPPH methods, Free Radical. Res. 30 (1999) 471-477.

19. A. B. A. El-Gazzar, H. N. Hafez, A. A. Abu-Hashem and A. S. Aly, Synthesis and antioxidant, anti-inflammatory, and analgesic activity of novel polycyclic pyrimido[4,5-b]quinolines, Phosphorus Sulfur 184 (2009) 379-405; DOI: 10.1080/10426500802167027.

20. A. B. A. El-Gazzar, A. M. S. Youssef, M. M. Youssef, A. A. Abu-Hashem and F. A. Badria, Design and synthesis of azolopyrimidoquinolines, pyrimidoquinazolines as anti-oxidant, anti-inflammatory and analgesic activities, Eur. J. Med. Chem. 44 (2009) 609-624; DOI: 10.1016/j. ejmech.2008.03.022.

21. R. Aeschlach, J. Loliger, C. B. Scott, A. Murcia, J. Butler, B. Halliwell and I. O. Aruoma, Antioxidant actions of thymol, carvacrol, 6-gingerol, zingerone and hydroxytyrosol, Food Chem. Toxicol. 32 (1994) 31-36.

22. T. Fujita, Y. Takeda, S. Han-dong, Y. Minami, T. Marunaka, S. Takeda, Y. Yamada and T. Togo, Cytotoxic and antitumor activities of Rabdosia diterpenoids, Planta Med. 54 (1988) 414-417; DOI: 10.1055 /s-2006-962485.

23. K. Gewald, E. Schink and H. Brottcher, Gewald aminothiophene synthesis, Chem. Ber. 99 (1966) 94-100.

24. V. Alagarsamy, S. Meena, V. K. Ramseshu, R. V. Solomon, K. Thirumurugan, K Dhanabal and M. Murugan, Synthesis, analgesic, anti-inflammatory, ulcerogenic index and antibacterial activities of novel 2-methylthio-3-substituted-5,6,7,8-tetrahydrobenzo $(b)$ thieno [2,3- $d$ ] pyrimidin-4(3H)-ones, Eur. J. Med. Chem. 41 (2006) 1293-1300. DOI: 10.1002/chin.200711131. 
A. A. Abu-Hashem et al.: Design and synthesis of novel thiophenecarbohydrazide, thienopyrazole and thienopyrimidine derivatives as antioxidant and antitumor agents, Acta Pharm. 60 (2010) 311-323.

\title{
$S A \check{Z} E T A K$
}

\section{Dizajniranje i sinteza novih derivata tiofenkarbohidrazida, tienopirazola $i$ tienopirimidina $s$ antioksidativnim $i$ antitumorskim djelovanjem}

\author{
AMEEN ALI ABU-HASHEM, MOHAMED FATHY EL-SHEHRY i FARID ABD-ELRAHEEM BADRIA
}

Etilni ester 2-amino-5-acetil-4-metil-tiofen-3-karboksilne kiseline (1) i 5-acetil-2-amino-4-metiltiofen-3-karbohidrazid (2) sintetizirani su i upotrebljeni kao reaktanti u sintezi novih spojeva 1-(5-amino-4-(3,5-dimetil-1H-pirazol-1-karbonil)-3-metiltiofen-2-il) etanona (3a), 1-(5-amino-4-(4-klor-3,5-dimetil-1H-pirazol-1-karbonil)-3-metiltiofen-2-il) etanona (3b), 1-(4-metil-2-amino-5-acetiltiofen-3-karbonil) pirazolidin-3,5-diona (4), (Z)- $N^{\prime}$-(4-metil-2-amino-5-acetiltiofen-3-karbonil) formohidrazonske kiseline (5a), (Z)-etil- $N^{\prime}$-(4-metil-2-amino-5-acetiltiofen-3karbonilformo hidrazonata (5b), 6-acetil-3-amino-2,5-dimetiltieno.2,3-d.pirimidin-4(3H)-one (8), 5-metil-3-amino-2-merkapto-6-acetiltieno.2,3-d.pirimidin-4(3H)-ona (10) i 5-metil-6-acetil-2-tiokso-2,3-dihidrotieno.2,3-d.pirimidin-4(1H)-ona (12) kao potencijalnih antioksidansa i citostatika. Farmakološka ispitivanja ukazuju na to da spojevi 6a, 6b, 8, 10 i 12 imaju značajno antitumorsko i antioksidativno djelovanje.

Ključne riječi: tienopirazol, tieno[2,3-d]pirimidini, tiofenkarbohidrazid, antioksidativno djelovanje, bleomicin-ovisno DNA oštećenje, antitumorsko djelovanje

Photochemistry Department (Heterocyclic Unit), National Research Center, 12622 Dokki, Giza, Egypt

Green Chemistry Department, National Research Center, 12622 Dokki, Giza, Egypt

Department of Pharmacognosy, Faculty of Pharmacy, Mansoura University, 35516 Mansoura, Egypt 